\title{
A Study of the Lipase Produced by Anaerovibrio lipolytica, a Rumen Bacterium
}

\author{
By C. HENDERSON \\ Rowett Research Institute, Bucksburn, Aberdeen, $A B 29 S B$ \\ (Accepted for publication 25 November 1970) \\ SUMMARY
}

\begin{abstract}
Anaerovibrio lipolytica strain $5 \mathrm{~s}$, an anaerobic rumen bacterium, produced an extracellular lipase during exponential growth in batch cultures. The lipolytic activity was excluded from Sephadex G-200, and the purest preparations obtained contained two components when examined by electrophoresis or by ultracentrifugation and a large proportion of nucleic acid. The enzyme was most active at $\mathrm{pH} 7.4$ and at 20 to $22^{\circ}$; activity was enhanced by $\mathrm{CaCl}_{2}$ or $\mathrm{BaCl}_{2}$ while $\mathrm{ZnCl}_{2}$ and $\mathrm{HgCl}_{2}$ were inhibitory. Sodium chloride at high concentration was also inhibitory. Trilaurin was most rapidly hydrolysed of the triglycerides but diglycerides were more rapidly hydrolysed than were triglycerides.
\end{abstract}

\section{INTRODUCTION}

A bacterium able to hydrolyse linseed oil triglycerides to glycerol and free fatty acids was isolated by Hobson \& Mann (196I) from the rumen of a sheep. Hungate (1966) designated it Anaerovibrio lipolytica and the behaviour of a strain (5S) in continuous culture was described by Hobson \& Summers (I966), Hobson \& Summers (1967) and by Henderson, Hobson \& Summers (I969). This paper describes an attempt to isolate, purify and characterize the enzyme or enzymes responsible for its extracellular lipolytic activity.

\section{METHODS}

Organism. The bacterium used was Anaerovibrio lipolytica strain $5 \mathrm{~s}$ of Hobson (1965).

Media. The bacteria were grown in a complex medium containing, per $100 \mathrm{ml}$.: 0.6 g. Difco yeast extract (Bacto Laboratories, Detroit, U.S.A.); 0.75 g. Casein hydrolysate (Oxoid Ltd, London); $15 \mathrm{ml} .0 .3 \%$ (w/v) dipotassium hydrogen phosphate; I $5 \mathrm{ml} .0 .3 \%(\mathrm{w} / \mathrm{v})$ potassium dihydrogen phosphate (AR grade); $0 . \mathrm{I} \mathrm{ml} .0 . \mathrm{I} \%(\mathrm{w} / \mathrm{v})$ resazurin; and Io $\mathrm{ml}$. solution (a), which contained $5 \%(\mathrm{w} / \mathrm{v})$ glycerol (AR grade), $0.5 \%$ (w/v) cysteine $\mathrm{HCl}$ (Biochemical reagent: British Drug Houses, Poole, Dorset) and $6 \%(\mathrm{w} / \mathrm{v})$ sodium bicarbonate (AR grade).

Solution $(a)$ was sterilized by Seitz filtration and added under a $\mathrm{CO}_{2}$ atmosphere to the basal medium, sterilized by autoclaving ( $12 \mathrm{I}^{\circ} / \mathrm{I} 5 \mathrm{~min}$.). These anaerobic media were prepared by techniques similar to those of Hungate (I950) and Hobson (I965).

Lipase assays. Lipase activity was measured as the rate of release of fatty acids from emulsified substrates. Emulsions were prepared from $100 \mathrm{mg}$. of substrate in $10 \mathrm{ml}$. 0.I M-phosphate buffer. The Dawe Soniprobe type II30 A (Dawe Instruments Ltd, 
Acton, London) tuned to maximum output produced a stable emulsion of suitable dispersion in 4 min.

When olive oil or triglycerides purified from olive oil were used as substrates, the extraction method of Dole \& Meinertz (1960) was used and the fatty acids liberated titrated with $0.01 \mathrm{~N}-\mathrm{NaOH}$ using Nile Blue sulphate $(0.01 \%$, w/v) dissolved in $9: \mathrm{I}(\mathrm{v} / \mathrm{v})$ ethanol: $\mathrm{H}_{2} \mathrm{O}$ as indicator. The alkali was stored under $\mathrm{CO}_{2}$-free conditions and standardized against oleic acid in $n$-heptane solution.

When short or medium chain length triglycerides were used, Cohen, Morgan \& Hofman's (1969) extraction method was employed and titrations performed with tetrabutyl ammonium hydroxide in toluene/methanol solution. This solution was standardized at about $0.0 \mathrm{I} \mathrm{N}$ using oleic acid in toluene solution with bromothymol blue $(0.1 \%(w / v)$ in absolute ethanol) as indicator for the single-phase titration.

In a typical experiment, $9 \mathrm{ml}$. of emulsion were incubated with $\mathrm{I} \mathrm{ml}$. enzyme preparation, I or $2 \mathrm{ml}$. samples of emulsion being removed at zero time and at $30 \mathrm{~min}$. for determination of free fatty acids. Activity is expressed in 'units', a unit being the amount of enzyme which releases I $\mu$ equiv. fatty acid/min., from emulsions of olive oil at $\mathrm{pH} 7.4$ and $20^{\circ}$.

Protein was estimated by the method of Lowry, Rosebrough, Farr \& Randall (I95I), with bovine serum albumin (Armour \& Co., London) as reference protein. Nucleic acid was determined by the method of Ogur \& Rosen (1950). Bacteria-free culture medium was prepared by centrifugation at $2000 \mathrm{~g}$ for $25 \mathrm{~min}$. Dry weights were measured on samples freeze-dried after exhaustive dialysis against distilled water. Total nitrogen in bacterial suspensions was measured by a micro-Kjeldahl method.

Materials. The cellulose powder was Whatman CF I I, and the collodion shells were from Sartorius-Membranfilter supplied by V. A. Howe \& Co. Ltd, London.

Tetrabutyl ammonium hydroxide was purchased as $\mathrm{N} /$ ro solution in methanoltoluene from B.D.H. and diluted to approximately 0.0 I $\mathrm{N}$ with methanol.

Tricaprylin, tricaproin, trilaurin and triolein were all obtained from Analytical Standards, Gothenburg, Sweden, and were greater than $99 \%$ pure.

Triglycerides from olive oil were isolated by chromatography on Alumina (May \& Baker, Cumbernauld, Dunbartonshire) as described by Jensen, Marks, Sampugna, Quinn \& Carpenter (I966). When examined by thin-layer chromatography on silicic acid, the purified preparations were found to contain only triglycerides. Tributyrin was laboratory reagent grade (B.D.H.). Olive oil (B.P.) was purchased from Boots (Chemists), Nottingham. Diolein was synthesized from its constituent compounds by the method of Mattson \& Volpenhein (1962). Thin-layer chromatography indicated the presence of free fatty acids in the synthesized diolein.

All other chemicals used were AR grade.

\section{RESULTS}

The production of lipase in batch cultures of Anaerovibrio lipolytica

Batch cultures of Anaerovibrio lipolytica were grown in a $300 \mathrm{ml}$. culture vessel at $38^{\circ}$, with $\mathrm{pH}$ measurement and control and with a flow of $\mathrm{O}_{2}$-free $\mathrm{CO}_{2}$ to stir the culture. Samples were removed at intervals and lipase in bacteria-free medium or in resuspended bacteria assayed, using olive oil as substrate. Total nitrogen measure- 
ments were made on bacterial suspensions and the $\mathrm{pH}$ recorded and controlled as desired.

Table I shows the results of three typical experiments. It was found that the enzyme activity began to appear in the bacteria-free medium soon after exponential growth of bacteria started, and then reached a peak and began to diminish as the culture went into stationary phase. The decrease in activity could be delayed if the culture $\mathrm{pH}$ was controlled at $6 \cdot 3$. No activity could be detected in the bacterial suspensions nor in bacteria which had been fragmented either by ultrasonic disintegration or by shaking with ballotini beads in a Mickle disintegrator.

\section{Table I. Lipase activities in batch cultures of Anaerovibrio lipolytica}

Parts $(a)$ and $(b)$ give results from two separate batch cultures growing without $\mathrm{pH}$ control; (c) gives results of one batch culture in which the $\mathrm{pH}$ was not allowed to drop below pH 6.3.

(a)

Culture age (h.)
Culture pH
Total bacterial nitrogen
(mg./ml. culture)
Activity/ml. in
(a) Bacteria-free
medium
(b) Bacterial
suspension*

Culture age (h.)

Culture pH

Total bacterial nitrogen (mg./ml. culture)

Activity/ml, in bacteriafree medium

$\begin{array}{ll}4.5 & 5.5 \\ 6.6 & 6.5 \\ 0.014 & 0.029\end{array}$

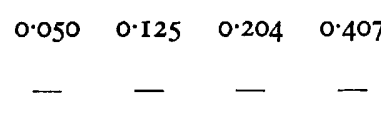

(b)

$\begin{array}{llccc}7.0 & 8.5 & 10.0 & \text { II.5 } & \text { 13.5 } \\ 6.3 & 6.1 & 5.9 & 5.8 & 5.7 \\ 0.043 & 0.086 & 0.095 & 0.091 & 0.093\end{array}$

$\begin{array}{ccccc}0.33 & 0.45 & 0.30 & 0.23 & 0.15 \\ 0.003 & 0 & 0.003 & 0.005 & 0.002\end{array}$

(c)

\begin{tabular}{lllllllll}
\hline 4 & 5 & 6 & 7 & 8 & 9 & 10 & II & 28 \\
6.5 & 6.45 & 6.40 & 6.30 & 6.3 & 6.3 & 6.3 & 6.3 & 6.3 \\
0.025 & 0.029 & 0.051 & 0.058 & 0.068 & 0.073 & 0.081 & 0.084 & 0.090 \\
0.040 & 0.125 & 0.130 & 0.273 & 0.350 & 0.375 & 0.345 & 0.340 & 0.260
\end{tabular}

* Bacterial suspensions contained the bacteria from $\mathrm{I} \mathrm{ml}$. culture resuspended in $\mathrm{I}$ ml. phosphate buffer.

Because of wide variations in the lag phase in batch cultures, it was difficult to predict when maximum enzyme activity would be attained. Also, since enzyme production was associated with growth of bacteria, continuous culture was chosen as a means of producing large amounts of enzyme. The apparatus used was similar to that of Hobson \& Summers (1967).

\section{Purification of the extracellular lipase of Anaerovibrio lipolytica}

The outflow from the continuous culture was collected in a glass vessel cooled to $\mathrm{I}^{\circ}$. When the bacteria were growing at a dilution rate of $0.09 \mathrm{~h} .^{-1}$ (mean doubling time of $7 \cdot 7 \mathrm{~h}$.) and the $\mathrm{pH}$ maintained at $6 \cdot 3$, large activities were measurable in the bacteriafree culture medium. The activity was maintained in the refrigerated vessel and this culture outflow provided a suitable starting material for enzyme isolation.

Initial attempts to concentrate the enzyme activity in bacteria-free medium by freeze-drying or ultrafiltration through collodion membranes were unsuccessful due to large losses of activity and the small volumes of medium which could be processed by these methods. The most successful method was an adaptation of that of Hofsten, 
van Kley \& Eaker (1965) for isolating a bacterial protease. Litre amounts of bacteriafree medium were half-saturated with ammonium sulphate and $2 \%(\mathrm{w} / \mathrm{v})$ of cellulose powder added. This suspension was stirred for $3 \mathrm{~h}$. at $\mathrm{I}^{\circ}$ and the cellulose removed by centrifugation. A glass column $320 \times 18 \mathrm{~mm}$. was packed with the wet cellulose and the lipolytic activity eluted in $30 \mathrm{ml} .0 . \mathrm{I}$ M-phosphate buffer, $\mathrm{pH} 7 \cdot 4$, dialysed for $16 \mathrm{~h}$. against distilled water and concentrated to $5 \mathrm{ml}$. by ultrafiltration through a collodion membrane. The enzyme preparation was then loaded on a Sephadex G-Ioo column (void volume $65 \mathrm{ml}$.) and eluted with $0 . \mathrm{I}$ M-phosphate buffer $\mathrm{pH} 7 \cdot 4$. The lipase was detected in the protein eluted in the buffer equivalent to the void volume, which was concentrated to $3 \mathrm{ml}$. by ultrafiltration, and further purified by chromatography on a Sephadex G-200 column (void volume $22 \mathrm{ml}$.). Fig. I shows the elution patterns obtained using Sephadex G-Ioo and Sephadex G-200 columns.

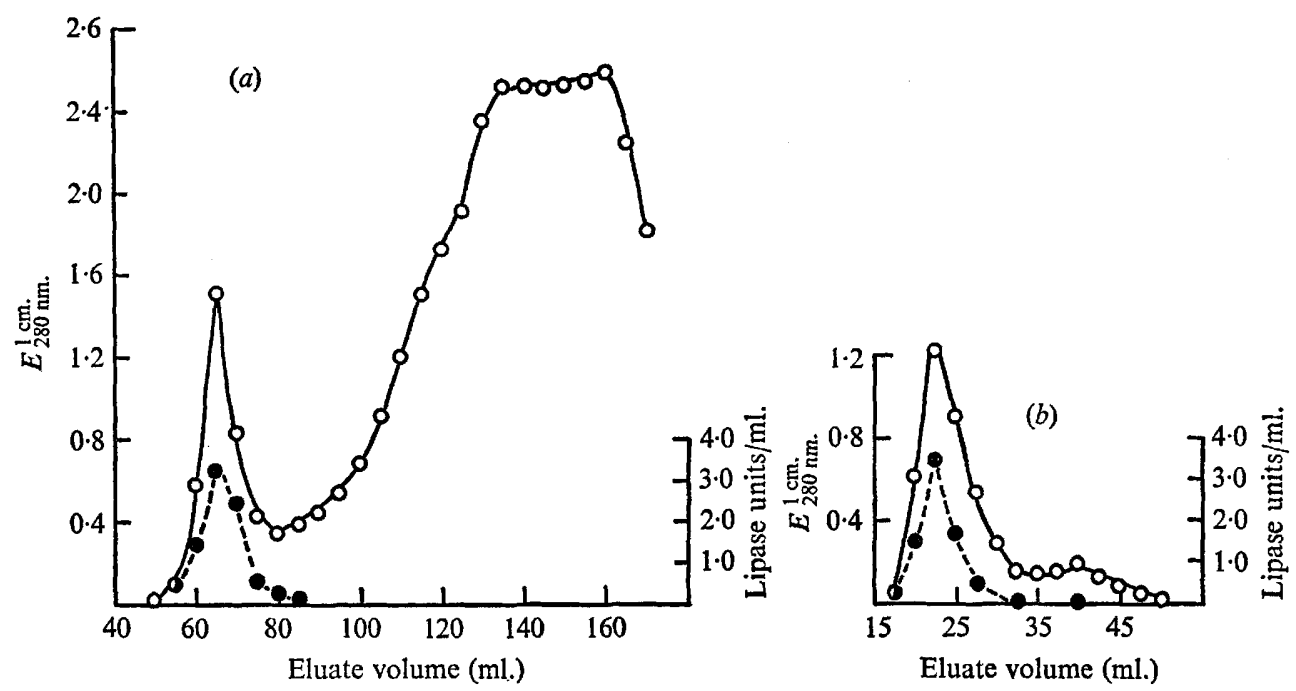

Fig. I (a). Gel filtration of the lipase of Anaerovibrio lipolytica on Sephadex G-I00. The lipase was eluted with $0 \cdot 1 \mathrm{M}$-phosphate buffer $\mathrm{pH} 7 \cdot 4$ and the $E_{280 \mathrm{~mm}}^{1 \mathrm{~cm}}(\mathrm{O}-\mathrm{O})$ of each eluate fraction was measured. Lipase assays $(--)$ were made on aliquots of the eluate. (b) Gel filtration of the lipase of Anaerovibrio lipolytica on Sephadex G-200. The lipase was eluted with $0.1 \mathrm{M}$-phosphate buffer $\mathrm{pH} 7.4$ and the $E_{280 \mathrm{~mm}}^{\mathrm{J}} .(\mathrm{O}-O)$ of each eluate fraction was measured. Lipase assays (--) were made on aliquots of the eluate.

\section{Table 2. Purification of the lipase of Anaerovibrio lipolytica}

Lipase assays and protein estimations were made at the following stages in the purification process: A, the culture medium from which bacteria had been removed by centrifugation; $\mathrm{B}$, the material eluted from the cellulose column, as described in the text, after dialysis; $\mathrm{C}$, the material eluted at the void volume from the Sephadex G-Ioo column; D, the material eluted at the void volume from the Sephadex G-200 column.

$\begin{array}{ccccc}\begin{array}{c}\text { Volume } \\ (\mathrm{ml})\end{array} & \text { Activity/ml. } & \begin{array}{c}\text { Protein } \\ \text { content } \\ (\mathrm{mg} . / \mathrm{ml} .)\end{array} & \begin{array}{c}\text { Specific } \\ \text { activity }\end{array} & \begin{array}{c}\text { Total } \\ \text { activity } \\ (\%)\end{array} \\ 1000.0 & 0.38 & 0.280 & 1 \cdot 36 & 100.0 \\ 55.0 & 1.88 & 0.250 & 7.50 & 27.2 \\ 34.5 & 1.26 & 0.060 & 21 \cdot 00 & 11.4 \\ 12.4 & 1.50 & 0.039 & 38.40 & 4.9\end{array}$


Table 2, giving the data on the purification procedure, shows that with a loss of $95 \%$ of the original activity a purification of 28 times was achieved. Further attempts at purifying the lipase using DEAE-cellulose or DEAE-Sephadex columns were unsuccessful since total loss of activity occurred.

Samples of lipase purified on Sephadex G-200 columns were concentrated by ultrafiltration and examined in the SPINCO model E analytical centrifuge. Samples containing $0.75 \%(\mathrm{w} / \mathrm{v})$ dry matter were sedimented at $59,780 \mathrm{rev} . / \mathrm{min}$. in $0 . \mathrm{I} \mathrm{M-}$ phosphate buffer $\mathrm{pH}_{7 \cdot 4}$ at $20^{\circ}$. Fig. 2 shows a typical Schlieren diagram and the enzyme is seen to contain a major and a minor component, the former having a sedimentation coefficient $\left(s_{20, \mathrm{w}}\right)$ of $5^{\circ}$, the latter of 13.8 Svedberg units.

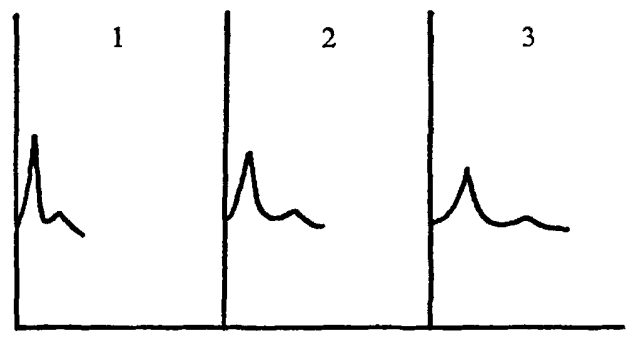

Fig. 2. Ultracentrifugal separation of the components of Anaerovibrio lipolytica lipase preparations. This figure is drawn from the photographic record of an ultracentrifugal separation in the SPINCO model E ultracentrifuge. The vertical lines represent the position of the meniscus and there was an $8 \mathrm{~min}$. interval between photographs.

Similar samples were electrophoresed on cellulose acetate strips using $0.06 \mathrm{M}$-barbitone buffer pH 8.6. Ten $\mu \mathrm{l}$. of a $0.75 \%$ (w/v) enzyme solution were applied to strips $200 \times 25 \mathrm{~mm}$. and separated for $2 \mathrm{~h}$. with an electrical current of $\mathrm{I} \cdot 25 \mathrm{~mA} / \mathrm{strip}$. Nigrosine solution $0.001 \%(\mathrm{w} / \mathrm{v})$ in $2 \%(\mathrm{v} / \mathrm{v})$ acetic acid) was used to locate protein and the enzyme samples were resolved into one discrete band which moved ahead of a second rather diffuse band.

Spectrophotometric assay of perchloric acid extracts of the enzyme preparations showed the presence of nucleic acid in a ratio of $3: 2$ with protein. The enzyme present in these preparations containing the two components was then examined.

A series of experiments was performed with olive oil. Earlier work (Henderson, 1968) had shown that $90 \mathrm{mg}$. oil in an emulsion volume of $9 \mathrm{ml}$. was a suitable substrate for assaying enzyme activities, when a total of not more than 0.6 enzyme units was present. Enzyme amounts were therefore kept below this limit.

Activity consistently reached a maximum at an assay $\mathrm{pH}$ of $7 \cdot 4$ with a uniform fall off on either side. The optimum activity was obtained over a shorter range with the purified enzyme than with the cruder preparations studied earlier (Henderson, I968). Fig. 3 describes two typical experiments.

Fig. 4 shows the effects of incubation temperature on two batches of enzyme of slightly different activities. The results have been corrected to an arbitrary activity of $\mathrm{I} \cdot \mathrm{O}$ at $20^{\circ}$. The optimum is at $20^{\circ}$ to $22^{\circ}$, which is much lower than the optimum of $38^{\circ}$ reported for the crude enzyme preparations (Henderson, 1968).

The effects of metallic cations were examined. The chlorides made up in concentrated solutions were added to oil emulsions to give the molarity required. Results are shown in Table 3. 
The hydrolysis of pure substrates, tributyrin, tricaproin, tricaprylin, trilaurin and triolein, was examined. Care has to be taken in interpreting the results since Dole's extraction method is inadequate for extracting short or medium chain length acids. The toluene-ethanol method of Cohen et al. (I969), a satisfactory alternative, was used to check these results. Dole \& Meinertz (1960) give a series of extraction ratios which can be used to correct for the incomplete extraction of short chain fatty acids. The results, using the toluene-ethanol method, agreed well with those from the heptaneisopropanol procedure corrected in this way. Table 4 shows the relative activities of Anaerovibrio lipolytica lipase towards these pure triglycerides and also towards olive oil, olive oil triglycerides, diolein and ethyl oleate.

After the enzymic hydrolysis of pure triglycerides, the hydrolysates were acidified

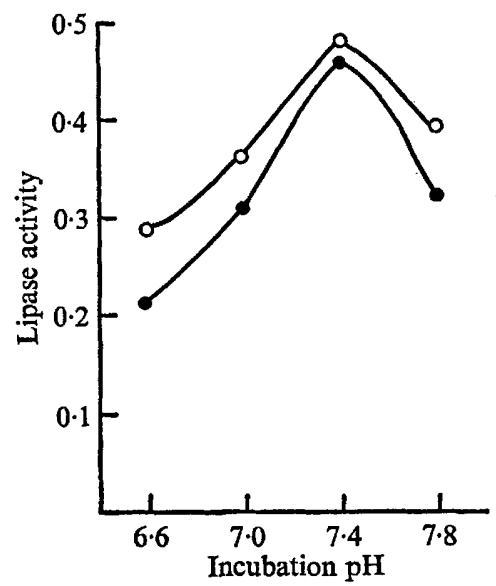

Fig. 3

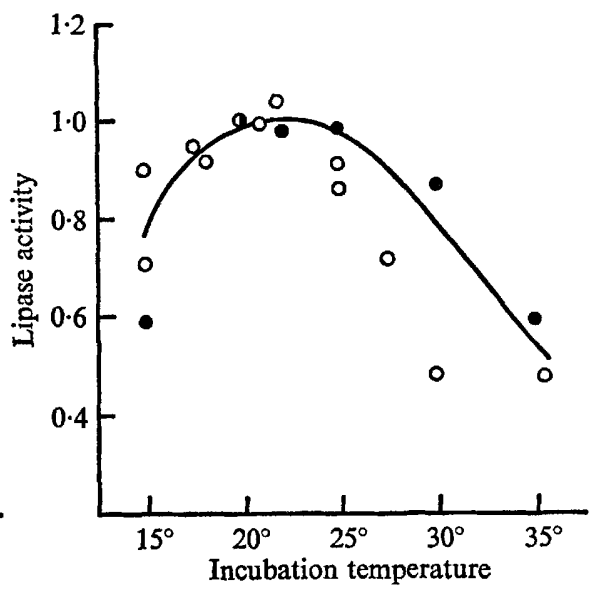

Fig. 4

Fig. 3. The effect of $\mathrm{pH}$ on lipase activity. Olive oil emulsions, made up in $0.1 \mathrm{M}$-phosphate buffer at various $\mathrm{pH}$ values, were incubated with lipase for $30 \mathrm{~min}$, at $20^{\circ}$ and enzyme activity measured as described in the text. Activity is expressed as $\mu$ equiv. fatty acid released/ min. The different symbols indicate different enzyme preparations.

Fig. 4. The effect of temperature on lipase activity. Olive oil emulsions, made up in 0.1 Mphosphate buffer $\mathrm{pH} \mathrm{7.4}$, were incubated with lipase for $30 \mathrm{~min}$. at various temperatures and enzyme activity measured as described in the text. Activities are expressed relative to the activity at $20^{\circ}$, which is taken as $1 \cdot 0$. The different symbols indicate different enzyme preparations.

Table 3. The effects of various cations on the hydrolysis of olive oil by the lipase of Anaerovibrio lipolytica

$\begin{array}{cccc}\text { Cation } & \text { Conc. (M) } & \begin{array}{c}\text { Inhibition } \\ (\%)\end{array} & \begin{array}{c}\text { Activation } \\ (\%)\end{array} \\ \mathrm{Ca}^{2+} & 5.0 \times 10^{-5} & 0 & 27 \\ & 1.0 \times 10^{-4} & 0 & 34 \\ \mathrm{Ba}^{2+} & 2.0 \times 10^{-4} & 0 & 36 \\ \mathrm{Zn}^{2+} & 1.0 \times 10^{-3} & 0 & 19.5 \\ \mathrm{Hg}^{2+} & 1.0 \times 10^{-3} & 26 & 0 \\ \mathrm{Na}^{+} & 1.0 \times 10^{-3} & 87 & 0 \\ & 1.6 \times 10^{-1} & 29 & 0 \\ & 2.4 \times 10^{-1} & 77 & 0 \\ & 4.5 \times 10^{-1} & 86 & 0\end{array}$


and extracted with diethyl ether. Examination of these extracts by thin-layer chromatography detected only fatty acids and residual triglycerides, mono- and diglycerides being absent.

\title{
Table 4. The hydrolysis of a series of substrates by the lipase of Anaerovibrio lipolytica
}

\begin{abstract}
Emulsions containing $90 \mathrm{mg}$. of substrate were incubated with purified lipase for $30 \mathrm{~min}$. at $20^{\circ}$. Enzyme activities were measured as described in the text and are expressed relative to the activity towards trilaurin.
\end{abstract}

$\begin{array}{lc}\text { Substrate } & \text { Activity } \\ \text { Tributyrin } & 0 \\ \text { Tricaproin } & 0.46 \\ \text { Tricaprylin } & 0.46 \\ \text { Trilaurin } & 1 \cdot 00 \\ \text { Triolein } & 0.55 \\ \text { Triglycerides from } & 0.64 \\ \quad \text { olive oil } & \\ \text { Olive oil } & \mathrm{I} \cdot 58 \\ \text { Diolein } & 2 \cdot 10 \\ \text { Ethyl oleate } & 0.17\end{array}$

\section{DISCUSSION}

Pollock (I962) gives three criteria which must be satisfied before an enzyme can be classified as extracellular. The lipase produced by batch cultures of Anaerovibrio lipolytica has been shown to satisfy the first two, namely, the lipase appears in the medium early in the life of the culture when little cell lysis has occurred, and secondly no lipase activity is found associated with the bacteria or with fragmented bacteria. Pollock's third test was not applied in this study. When the stationary phase is approached the enzyme production ceases and in the acid conditions which develop in uncontrolled cultures rapid loss of enzyme activity occurs.

The complete purification of the lipase has not been possible. Large losses accompanied every attempt to concentrate the small amount of activity present in large volumes of culture medium. Even the best method, ammonium sulphate precipitation and cellulose adsorption involved a loss of over $70 \%$ of the initial activity, perhaps due to some irreversible adsorption of the enzymes on the cellulose. Downey \& Andrews (1965) argued that the ability of lipases to attack emulsified substrates suggested that lipases possessed special adsorptive properties which could lead to losses of enzyme on Sephadex columns. A similar phenomenon could explain total loss of activity on DEAE-Sephadex and DEAE-cellulose columns.

Spectrophotometric and chemical analysis of the enzyme preparations from Sephadex G-200 columns showed a complex mixture of nucleic acid and protein. These preparations could be resolved into two components in the analytical ultracentrifuge or by electrophoresis on cellulose acetate. Because it has been impossible to separate these two components on a preparative scale, it is not known whether both have lipolytic activity or what the chemical composition of each component is. The complex nature of the enzyme preparation is similar to that of the proteinase of Blackburn (1968) from another rumen bacterium.

Lipase preparations, purified on Sephadex G-200, have an optimum activity at $7 \cdot 4$. This is typical of microbial lipases and Lawrence (I967) lists a number of lipases which are most active at, or just above, neutrality. The temperature optimum of the purified 
lipase was much lower than that reported earlier (Henderson, 1968) for crude preparations. This is probably due to the removal of medium components exerting a stabilizing effect on the more impure enzyme. The effects of peptone in the medium on the heat stability of impure bacterial lipases have been described by Lawrence, Fryer \& Reiter (1967).

The effects of calcium and barium cations are compatible with a role in removing fatty acids from the active site area as insoluble salts, as suggested by Desnuelle (I96I), for the effects of calcium on pancreatic lipase. Zinc and mercury ions were potent enzyme poisons as indicated by the results of Lawrence et al. (1967). The inhibitory effect of high concentrations of sodium chloride is in agreement with results on other microbial lipases of Morris \& Jezeski (I953) and Imamura (1960). Hobson (1965) also noted that lipase production by Anaerovibrio lipolytica (5s) was greater when $\mathrm{NaCl}$ was absent from the medium.

Care has to be taken in interpreting the significance of the enzyme activity towards different triglycerides solely in terms of fatty acid chain length since the various substrates have widely varying physical properties and the state of the emulsion has a profound effect on the course of the reaction. However, the largest activity towards pure triglycerides was obtained with trilaurin which was the most difficult to prepare in fine emulsion. Olive oil is a more favourable substrate than the triglycerides isolated from it, perhaps because of the presence of diglycerides which were more rapidly attacked than triglycerides, a finding which accounts for the absence of diglyceride in the hydrolysates from pure triglycerides. This property also gives an interesting link between the enzyme and what may be its natural substrate since in pasture-fed ruminants most of the neutral lipids are in the form of galactosyldiglycerides which yield diglycerides after attack by galactosidases.

I wish to thank Mr J. Stewart for performing the ultracentrifugal analyses. I also wish to thank Dr P. N. Hobson for helpful discussions, and Mr E. Forbes for skilled technical assistance.

\section{REFERENCES}

BLACKBuRn, T. H. (I968). The protease liberated from Bacteroides amylophilus strain HI8 by mechanical disintegration. Journal of General Microbiology 53, 37-5I.

Cohen, M., Morgan, R. G. H. \& Hofman, A. F. (1969). One-step quantitative extraction of mediumchain and long-chain fatty acids from aqueous samples. Journal of Lipid Research ro, 614-6I6.

Desnuelle, P. (1961). Pancreatic lipase. Advances in Enzymology 23, 129-16r.

Dole, V. P. \& MeInertz, H. (1960). Micro determination of long-chain fatty acids in plasma and tissues. Journal of Biological Chemistry 235, 2595-2599.

Downey, W. K. \& ANDrews, P. (1965). Gel filtration applied to the study of lipases and other esterases. Biochemical Journal 94, 642-650.

Henderson, C. (1968). A study of the lipase of Anaerovibrio lipolytica: a rumen bacterium. Ph.D. Thesis, University of Aberdeen.

Henderson, C., Hobson, P. N. \& Summers, R. (1969). The production of amylase, protease and lipolytic enzymes by two species of anaerobic rumen bacteria. In Proceedings of the Fourth Symposium on Continuous Cultivation of Micro-organisms, Prague, pp. 189-204. London: Academic Press.

Hobson, P. N. (1965). Continuous culture of some anaerobic and facultatively anaerobic rumen bacteria. Journal of General Microbiology 38, 167-180.

HoBson, P. N. \& MANN, S. O. (I96I). The isolation of glycerol-fermenting and lipolytic bacteria from the rumen of the sheep. Journal of General Microbiology 25, 227-240. 
Hobson, P. N. \& Summers, R. (1966). Effect of growth rate on the lipase activity of a rumen bacterium. Nature, London 209, 736-737.

Hobson, P. N. \& Summers, R. (1967). The continuous culture of anaerobic bacteria. Journal of General Microbiology 47, 53-65.

Hofsten, B. V., VAN KLEY, H. \& EAKER, D. (1965). An extracellular proteolytic enzyme from a strain of Arthrobacter. II. Purification and chemical properties of the enzyme. Biochimica et biophysica acta II0, 585-598.

Hungate, R. E. (1950). The anaerobic mesophilic cellulolytic bacteria. Bacteriological Reviews 14, I-49.

Hungate, R. E. (1966). The Rumen and Its Microbes, p. 80. London: Academic Press.

Imamura, T. (1960). Studies on the changes of milk fat by Penicillium roqueforti. Part II. Lipolysis by enzyme preparation. Journal of the Agricultural Chemical Society of Japan 34, 383-387.

Jensen, R. G., Marks, T. A., Sampugna, J., Quinn, J. G. \& Carpenter, D. L. (I960). Purification of triglycerides with an alumina column. Lipids I, 45I-452.

LAWRENCE, R. C. (1967). Microbial lipases and related esterases. Part II. Estimation of lipase activity. Characterization of lipases. Recent work concerning their effect on dairy products. Dairy Science Abstracts 29, 59-70.

LAwrence, R. C., Fryer, T. F. \& Reiter, B. (1967). The production and characterization of lipase from a micrococcus and a pseudomonad. Journal of General Microbiology 48, 401-418.

Lowry, O. H., Rosebrough, N. J., FARR, A. L. \& RaNDall, R. J. (I95I). Protein measurement with the Folin phenol reagent. Journal of Biological Chemistry 193, 265-275.

Mattson, F. H. \& Volpenhein, R. A. (1962). Synthesis and properties of glycerides. Journal of Lipid Research 3, 281-296.

MORRIS, H. A. \& JESESKI, J. J. (1953). The action of micro-organisms on fat. II. Some characteristics of the lipase system of Penicillium roqueforti. Journal of Dairy Science 36, 1285-1298.

OGUR, M. \& Rosen, G. (1950). The nucleic acids of plant tissues. I. The extraction and estimation of desoxypentose nucleic acid and pentose nucleic acid. Archives of Biochemistry and Biophysics 25, $262-276$.

Pollock, M. R. (1962). Exoenzymes. In The Bacteria, vol. 4, pp. I 2 I-178. Edited by I. C. Gunsalus and R. Y. Stanier. New York and London: Academic Press. 